\title{
Endoparasites of Selected Native Non-Domesticated Mammals in the Neotropics (New World Tropics)
}

\author{
Kegan Romelle Jones ${ }^{1,2, *}$, Kavita Ranjeeta Lall ${ }^{2}$ and Gary Wayne Garcia ${ }^{2}$ \\ 1 The Department of Basic Veterinary Sciences (DBVS), School of Veterinary Medicine (SVM), \\ University of the West Indies (UWI), Mt. Hope, Trinidad and Tobago \\ 2 The Open Tropical Forage-Animal Production Laboratory (OTF-APL), Department of Food \\ Production (DFP), Faculty of Food and Agriculture (FFA), The University of the West Indies (UWI), \\ St. Augustine, Trinidad and Tobago; k_lee_24@yahoo.com (K.R.L.); prof.gary.garcia@gmail.com (G.W.G.) \\ * Correspondence: keganjones11@gmail.com; Tel.: +1-868-787-0833
}

Received: 1 June 2019; Accepted: 18 October 2019; Published: 30 October 2019

\begin{abstract}
In this review, information was summarized on endoparasites found in six non-domesticated neotropical animals. These mammals have the potential to be domesticated. The animals included three rodents, agouti (Dasyprocta leporina), lappe (Agouti paca), and capybara (Hydrochoerus hydrochaeris); a marsupial, manicou (Didelphis marsupialis insularis); and an artiodactyl, the collared peccary (Tayassu tajacu/Peccari tajacu) and a ruminant (the red brocket deer, Mazama americana). While there are many descriptions of the parasites present, the majority of publications failed to note the effect of them on the animals. Most information is available on endoparasites of capybara, while the endoparasites of the red brocket deer were the least reported. The manicou was reported to have had the most number of endoparasites, 44 species of parasites were reported, while there were only 24 endoparasites reported in the lappe. The most common parasites found in these neotropical animals were Paraspidodera uncinata, Strongyloides spp., Eimeria spp., Moniezia benedeni, Trichuris spp., Physocephalus spp., and Giardia spp. A large majority of the studies concluded that these animals were reservoirs for parasites that could affect domesticated livestock. Endoparasites of zoonotic significance were Echinoccocus spp., Trichuris spp., Giardia spp., and Cryptosporidium spp.
\end{abstract}

Keywords: Dasyprocta leporina; Agouti paca; Hydrochoerus hydrochaeris; Didelphis marsupialis insularis; Tayassu tajacu; Peccari tajacu; Mazama amaericana

\section{Introduction}

In this review, updates were made on the current knowledge of endoparasites in non-domesticated animals with the potential for domestication. These animals have the potential to be meat protein sources for rural communities. Former reviews on endoparasites in the neotropics summarized the information on cattle (Bos indicus and Bos taurus), sheep (Ovis averies), goats (Capri hircus), horses, (Equus caballi), pigs (Sus sucrofa), and chickens (Gallus domesticus) [1]. Endoparasites mainly found in these domesticated animals were Strongylus vulgaris in horses, Hyostrongylus rubidis in pigs, Haemonchus contortus in ruminants, and Heterakis gallinarum in chickens. Some endoparasites of ducks (Anas platyrhynchos and Cairina moschata), turkeys (Melaegradis gallopavo), chinchillas (Chinchillas lanigera), guinea pigs (Cavia porcelleus), and south american camelids (Lama glama, Lama pacos, Lama gunacoa, and Vicuna vicuna) were Nematodirus spp., Trichostrongylus spp., Giardia duodenalis, Cryptosporidium spp., and Ascaridia gallinarum [2].

Since these six native neotropical animals have potential for domestication [3], it is required to focus on factors which affect animal production. These factors are (i) feeding and nutrition, (ii) reproduction and breeding, (iii) health and disease, (iv) housing and environement, (v) economic and socioeconomic 
factors, and (vi) animal behavior and psycology [3,4]. Recently, the agouti, D. leporina, has been studied in more detail, with focus on the anatomy of the male and female reproductive system, oestrus cycle in the female (28-31 days) as well as semen analysis using electroejaculation [5-8] Further anatomical investigations of the digestive system of the agoutis revealed that the majority of the gastrointestinal tract was small intestine in conjunction with a large cecum [9]. The agoutis mainly are frugivorous with the majority of the diet consisting of nuts and fruits, with potentially a preferential particle size [10-13]. Earlier it was found that these animals were rather omnivorous and would consume eggs and chicks [14]. It is clear that there is a need for more investigation on their feeding habits. Several studies have reported on the blood values of captive reared animals, and differences in diets and environments did not affect those values [15]. As such, blood values are a good basis for determination of the health status of neotropical mammals.

The lappe was decribed as a frugivore, the manicou as an omnivore, the collared peccary as a pseudo-ruminant herbivore, and the red brocket deer was grouped with ruminants [12-19]. The manicou has a gestation period of three weeks $[17,18]$. Other information on these species is lacking. The objective of this review was to summarize the knowledge of endoparasites found in six native non-domestic neotropical animal species. These neotropical animals are potential sources of meat protein which can be utilized by rural communities.

\section{Agouti (Dasyprocta spp.)}

The earliest work on the gastrointestinal parasites of the agouti, D. leporina, was done in the mid 1930s. Strongyloides agoutii was described in the feces of the agouti. This parasite has a similar life cycle as the other species of the Strongyloides genus [20]. Similar work was done on agoutis found in Trinidad, but the entrails of the animals were analyzed for gastrointestinal parasites. In the early 1950s, the amphistome, Stichorchis giganteus; the tapeworm, Raillietina demerariensis var. trinitatae; and seven roundworms including Strongyloides agouti, Trichuris gracilis var. trinitatae, Acanthocheilonema spp., Fuellebornema agoutii, Pudica pudica, Aspidodera binansata var. agoutiae, and Helminthoxys urichi were detected in the agouti [21].

In presumed healthy wild agoutis from Trinidad, Trichuris gracilis var. trintatae (in cecum and large intestines), Strongyloides agouti, Helminthoxys urichi, Eimeria spp., ascarid-like ova (unidentified species), trematode (unidentified species), and an unidentified cestode were detected [22] and more recently in intensively reared agouti (D. leporina), Strongyloides spp. was found in 36.9\%, Trichuris spp. in $4.62 \%$, and Paraspidodera uncinata in $15.4 \%$ of the agoutis sampled $(n=65)$. Despite the presence of these parasites, the animals were in good body condition (average body condition score of 3 out of 5) and had no history of gastrointestinal illness [23]. Using fecal floatation techniques, Trichuris spp. were found at a concentration of $2.2 \times 10^{2}$ eggs/gram, Strongyloides spp. at $4.28 \times 10^{2}$ eggs/gram, and Eimeria spp. at $2.15 \times 10^{3}$ oocysts/gram, all with no signs of gastrointestinal illness and a body condition score of 3 out of 5 [24].

In Paraguay, wild agoutis (D. azarae) were positive for Pudica pudica, Pudica gonosoma, Durettestrongylus baudi, Fuellebornema granulosa, and Fuellebornema demarsae [25]. In several studies in Brazil, agouti parasites that were found included Trichuris spp. (cecum), Eucyathostomum copulatum, Helminthoxys urichi (cecum and intestines), Physocephalus meridionalis (large intestine) and Dipetalonema spp. (body cavity), Eucyathostomum copulatum (large intestine), Heligmostrongylus agouti, H. almeidai, Heligmostrongylus sedecimradiatus, Monodontus aguiari, Pudica pudica, Pereiraia spp., Physocephalus meridionalis, Trichuris gracilis (cecum), Raillietina trinitae (small intestine), Physaloptera toressi, P. mediospiralis (stomach), Freitastrongylus angelae (stomach), Vianella trichospicula, and Avellaria intermedia were found [26-35]. The Eimeria spp. identified were E. aguti, E. cotiae, and E. paraensis. The predilection site of these protozoan parasites was the small intestines, but none of the infected animals showed signs of illness and the fecal pellets found were of normal consistency [31]. Reported prevalences were $45.3 \%$ (24/53) for protozoan oocysts, $10.8 \%$ (7/53) for Trichuris spp. eggs, and 18.8\% (10/53) for Strongyloides spp. [29]. 
In a zoo in Mephis Tennessee, Echinococcus oligarthrus hydatid cysts and Strongyloides spp. were found in healthy Brazilian agoutis from Guyana. These animals were treated with ivermectin $(0.7 \mathrm{mg}$ subcutaneously, twice daily for 14 days), praziquantel (28.4 mg intramuscularly, twice daily for 30 days), and albendazole (65 mg per os, once a day for 30 days) and some of the subcutaneous cysts were removed surgically [36]. In the studies performed in Argentina, similar parasites as to those mentioned above were found [37].

Other treatments that were reported included fenbendazole ( $5 \mathrm{mg} / \mathrm{kg} /$ day for 5 days) and piperazine citrate $(180 \mathrm{mg} / \mathrm{kg} /$ day for 5 days), and the efficacy reported with these treatments were poor [38]. Most authors identified various parasites in captive-reared and wild agoutis in the neotropical region; however, only a few made reference to the effect these parasitic organisms had on the animals' health and body condition. A summary of the endoparasites found in the agouti at different locations and the effects on the animals (host) can be seen in Table 1.

Table 1. Endoparasites found in the agouti (Dasypocta spp.) at different locations and points in time.

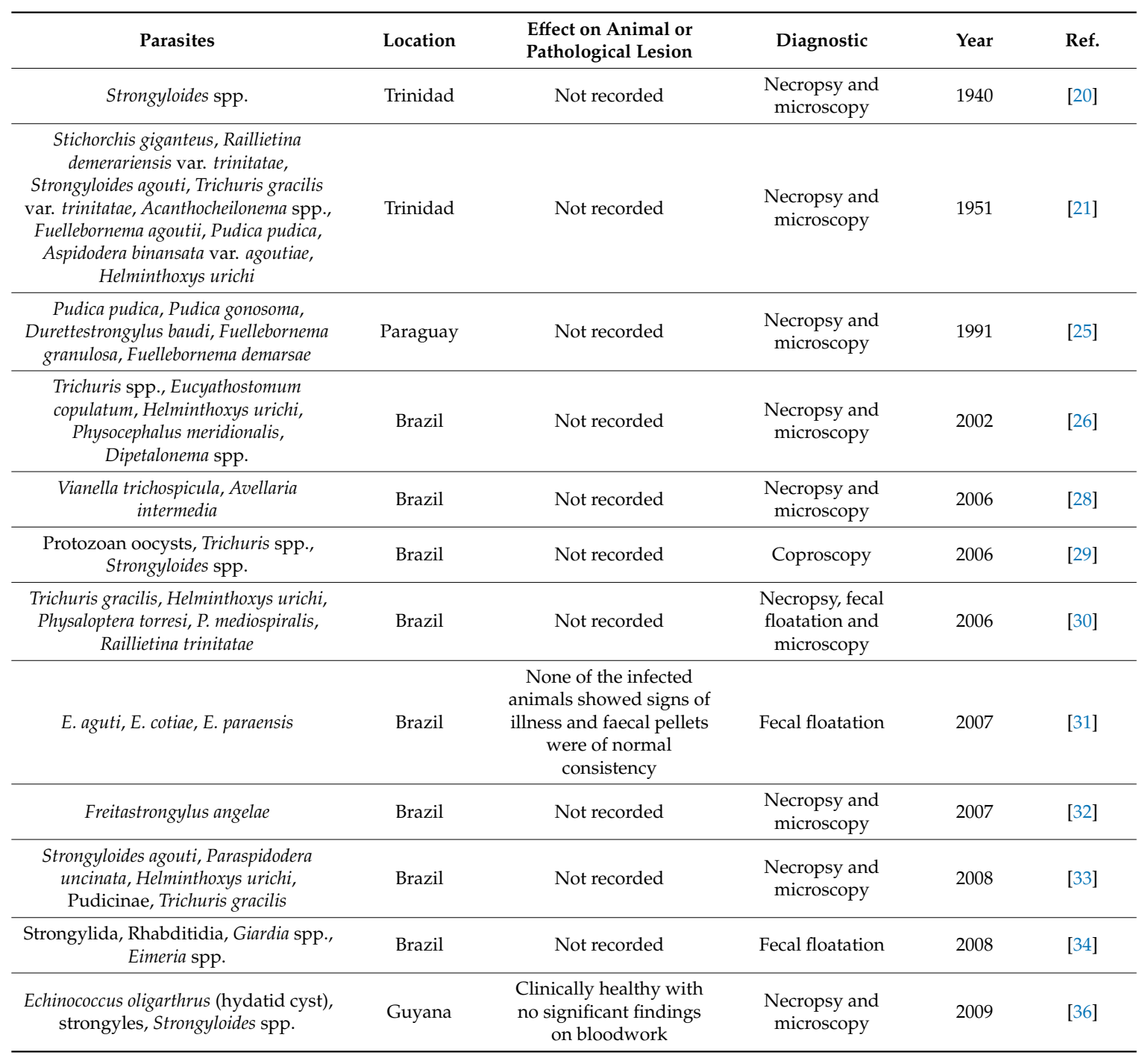


Table 1. Cont

\begin{tabular}{|c|c|c|c|c|c|}
\hline Parasites & Location & $\begin{array}{l}\text { Effect on Animal or } \\
\text { Pathological Lesion }\end{array}$ & Diagnostic & Year & Ref. \\
\hline $\begin{array}{l}\text { Trichuris gracilis var. trintatae, } \\
\text { Strongyloides agouti, Helminthoxys } \\
\text { urichi, Eimeria spp., ascarid-like ova } \\
\text { (unidentified species), trematode } \\
\text { (unidentified species), cestode } \\
\text { (unidentified species) }\end{array}$ & Trinidad & $\begin{array}{l}\text { Presumed to the healthy } \\
\text { animals }\end{array}$ & $\begin{array}{l}\text { Necropsy, fecal } \\
\text { floatation and } \\
\text { microscopy }\end{array}$ & 2016 & [22] \\
\hline $\begin{array}{l}\text { Strongyloides spp., Trichuris spp., } \\
\text { Paraspidodera uncinata }\end{array}$ & Trinidad & $\begin{array}{c}\text { All animals were in good } \\
\text { body condition (average } \\
\text { score of } 3 \text { out of 5) and } \\
\text { no history of } \\
\text { gastrointestinal illness }\end{array}$ & Fecal floatation & 2017 & [23] \\
\hline
\end{tabular}

\section{Lappe (Agouti paca/Cuniculus paca)}

Most of the studies on lappe were from Brazil and the following parasites were found: Heligmostrongylus sedecimradiatus, Longistriata breviscapula, Oswaldonema cruzi, Oswaldonema skrjabini, Paraspidodera uncinata, Paraspidodera spp., Pereiraia spp., Turgida torresi, Trichuris spp., and Vianella avellari. Physocephalus spp. was found in the stomach, and Strongyloides spp. and Strongylus spp. were found in the small intestine. Heligmostrongylus agouti and Physocephalus meridionalis were found in the stomach and Echinococcus vogeli and Calodium hepaticum were found in the liver [26,27,39].

Few studies reported the pathology casued on internal organs by the endoparasites. The liver pathology potentially caused by Echinococcus vogeli and Calodium hepaticum was characterized by fibrosis with a scanty infiltrate of lymphocytes and macrophages [39] and the histopathological lesions of Physocephalus spp. in the stomach showed congestion, interstitial hemorrhaging, and mononuclear inflammatory infiltrates [40]. In a breeding farm in Brazil, Eimeria spp., Strongyloides spp., Trichuris spp., and Hymenolepis diminuta were found and managed by anthelmintics and sanitation [41]. Quick lime was also used as an anthelmintic treatment for the larval stages of the parasites in the soil [42].

In a few other countries, the Strongyloides spp. were found [43]. In Costa Rica, Strongyloides spp., Strongylida, Eimeria agouti, Capillaria spp., Ascaroidea, Taenia spp., and Trichuris spp. were found in the gastrointestinal tracts [44]. In Mexico, Strongyloides spp., Strongylida, Trichuris spp., and Eucoccidia were found [45] and in Venezuela, Raillietina demerariensis (a cestode) was found [46].

Echinococcus spp. take a special place in the list of parasites found in the lappe as they are zoonotic. They have been found in Columbia where approximately $47 \%$ (44/93) of the lappe were found to be infected [47]. In Bolivia as well as Peru, Echinococcus vogeli was found but there were no relyable prevalence figures available [48-50]. A later study in Peru demonstrated larval cysts of E. vogeli in $12 \%$ of the lappe (15/120) [51].

Echinococcosis has been reported as being zoonotic and the agouti (D. leporina) and the lappe (A. paca) are the intermediate hosts of E. vogeli and E. oligarthrus. However, humans become infected via the ingestion of eggs that come from the adult parasites present in dogs [51-56]. All data on endoparasites in the lappe are summarized in Table 2. 
Table 2. Endoparasites found in the lappe (Cuniculus paca/Agouti paca) at different locations.

\begin{tabular}{|c|c|c|c|c|c|}
\hline Parasites & Location & $\begin{array}{l}\text { Effect on Animal or } \\
\text { Pathological Lesion }\end{array}$ & Diagnosis & Year & References \\
\hline $\begin{array}{c}\text { Heligmostrongylus sedecimradiatus, } \\
\text { Longistriata breviscapula, } \\
\text { Oswaldonema cruzi, Oswaldonema } \\
\text { skrjabini, Paraspidodera uncinata, } \\
\text { Paraspidodera spp., Pereiraia spp., } \\
\text { Turgida torresi, Trichuris spp., } \\
\text { Vianella avellari }\end{array}$ & Brazil & Not recorded & $\begin{array}{l}\text { Necropsy and } \\
\text { microscopy }\end{array}$ & 1997 & [27] \\
\hline $\begin{array}{c}\text { Strongyloides spp., Strongylus spp., } \\
\text { Heligmostrongylus agouti, } \\
\text { Physocephalus meridionalis }\end{array}$ & Brazil & Not recorded & $\begin{array}{l}\text { Necropsy and } \\
\text { microscopy }\end{array}$ & 2002 & [26] \\
\hline $\begin{array}{c}\text { Echinococcus vogeli, Calodium } \\
\text { hepaticum }\end{array}$ & Brazil & $\begin{array}{l}\text { Liver fibrosis with an } \\
\text { infiltrate of lymphocytes } \\
\text { and macrophages }\end{array}$ & $\begin{array}{l}\text { Necropsy and } \\
\text { microscopy }\end{array}$ & 2013 & [39] \\
\hline Physocephalus spp. & Brazil (Tocantins) & $\begin{array}{l}\text { Congestion, interstitial } \\
\text { hemorrhaging, and } \\
\text { mononuclear infiltrates }\end{array}$ & $\begin{array}{l}\text { Necropsy and } \\
\text { microscopy }\end{array}$ & 2012 & [40] \\
\hline $\begin{array}{c}\text { Eimeria spp., Strongyloides spp., } \\
\text { Trichuris spp., Hymenolepis } \\
\text { diminuta }\end{array}$ & Brazil & Not recorded & Fecal floatation & 2018 & [41] \\
\hline Strongyloides spp. & Brazil (Sao Luis) & Not recorded & $\begin{array}{l}\text { Necropsy and } \\
\text { microscopy }\end{array}$ & 2018 & [43] \\
\hline $\begin{array}{c}\text { Strongyloides spp., Strongyloidea, } \\
\text { Eimeria agouti, Capillaria spp., } \\
\text { Ascaroidea, Taenia spp., Trichuris } \\
\text { spp. }\end{array}$ & Costa Rica & Not recorded & $\begin{array}{l}\text { Necropsy and } \\
\text { microscopy }\end{array}$ & 1991 & [44] \\
\hline $\begin{array}{l}\text { Strongyloides spp. Strongylida, } \\
\text { Trichuris spp., Eucoccidia }\end{array}$ & Mexico & Not recorded & Coproscopy & 2001 & [45] \\
\hline Raillietina demerariensis & Venezuela & Not recorded & $\begin{array}{l}\text { Necropsy and } \\
\text { microscopy }\end{array}$ & 1988 & [46] \\
\hline Echinococcus spp. & Columbia & $\begin{array}{l}\text { Cysts found in liver and } \\
\text { peritoneum }\end{array}$ & $\begin{array}{l}\text { Necropsy and } \\
\text { microscopy }\end{array}$ & 1979 & [47] \\
\hline Echinococcus vogeli & Bolivia & Not recorded & $\begin{array}{l}\text { Necropsy and } \\
\text { microscopy }\end{array}$ & 1988,2013 & {$[48,49]$} \\
\hline
\end{tabular}

\section{Capybara (Hydrochoerus hydrochaeris)}

The first reports that were made in Panama on endoparasites was in the 1930s and amphistomate flukes (Taxorchis schistocotyle) were detected in a dead animal. However, no lesions were found in the intestinal tract. [57]. Another case report came from the San Diego Zoo, where Balantidium coli was associated with mortality as well as mucoid diarrhea. Histological findings of the colon found ulceration and cellular infiltrates that consisted of eosinophils, macrophages, and plasma cells [58]. In Brazil, the death of a capybara was associated with four specimens of trematodes, Trichostrongylidae, Eimeria, and Strongyloides spp. There was multifocal fibrosis with marked thickening of the liver capsule and granulomatous thickening of the bile ducts [59]. Eimeria ichiloensis and Eimeria trinidadensis have been associated with diarrhoea in the capybara [60].

In Brazil, numerous studies have been conducted on the gastrointestinal parasites of capybaras. Taxorchis schistocotyle, Cruorifilaria tuberocauda, Eucoleus hydrochoeri, Echinocoleus hydrochaeri, Habronema clarki, Hydrochoerisnema anomalobursata, Protozoophaga obesa, Strongyloides chapini, Trichostrongylus axei, Vianella hydrochoeri, Yatesia hydrochoerus, Monecocestus hagmanni, M. hydrochoeri, M. macrobursatum, M. hagmani, and H. fuelleborni have been found in capybaras. Capillaria hydrochoeri, Philophthalmus lachrymosus, Hippocrepis hippocrepis, Neocotyle neocotyle, Fasciola hepatica, Nudacotyle tertius, Nudacotyle valdevaginatus, Taxorchis schistocotyle, Eimeria ichiloensis, Fasciola hepatica, Eimeria spp., cestodes, Trichostrongylidae, Capillaria spp., Anoplochephalidae, Ascaridae, and M. jacobi have also been found $[27,35,61-68]$.

Three more detailed studies on both juvenile and adult capybaras located the helminths at their predilection sites: Trichostrongylus axei (stomach and small intestines), Vianella hydrochoeri 
(stomach and small intestines), Strongyloides chapini (stomach and small intestines), Yatesia hydrochoerus, Cruorifilaria tubercauda, and Capillaria hydrochoeri (stomach and small intestines), Protozoophaga obesa (pyloric region of the stomach, cecum, colon, and rectum), Taxorchis schistocotyle (small and large intestines including cecum), Hippocrepis hippocrepis (small intestine, colon, and rectum), Nudacotyle tertius and Monoecocestus hydrochoeri (small intestines), Hydrochoerisnema anomalobursata (stomach and small intestine), Monoecocestus hagmanni (small intestine), M. macrobursatum (small intestine), Monoecocestus hagmanni (small intestine), and Philophthalmus lachrymosus (vitreous humour). Stongyloides spp. (stomach), Habronema spp. (stomach), Vianella hydrochoeri (stomach and small intestine), Hydrochoeristrema cabrali (cecum) [66,69-71] and S. chapini had a higher prevalence in juvenile animals in comparison with adults, while for Y. hydrochoerus and C. hydrochoerid, the opposite was recorded [69].

A more epidemiology-based study on 45 samples showed that $5.52 \%$ of the samples were positive for C. paroum [72], while another study showed that, of the 250 samples tested, $52.4 \%$ were positive for Eimeria trinidadensis, Eimeria ichiloensis, Eimeria boliviensis, and Eimeria araside [73]. Nine percent of 134 capybaras were found positive for Fasciola hepatica [74]. In 31 free ranging capybaras, 58\% were positive for Protozoophaga spp., 23\% for Vianella spp., 10\% for Strongyloides spp., and 10\% for Ancylostomatidae [75]. In Argentina, about 70\% of the capybaras were found positive for endparasites and infections with multiple parasites and protozoa were higher in young animals and in spring. Parasites found included: Eimeria spp., Blastocystis spp., Balantidium coli, Ascaridia, Trichostrongylidae, Protozoophaga obesa, Strongyloides spp., Capillaria hydrochoaeri, Monoecocestus hydrochoerid, and Taxorchis schistocotyle [76]. Other studies in Argentina found Fasciola hepatica, Echinocoleus hydrochoerid, and Taxorchis schistocotyle [77,78]. In 2019, a new species named Trichuris cutillasae was identified in the cecum of capybaras [79].

In Bolivia, in the mid 1990, helminths including Monoecocestus hagmanni, M. hydrochoeri, M. macrobursatum, Habronema clarki, Vianella hydochoeri, Protozoophaga obesa, Taxorchis schistocotyle, and Hippocrepis hippocrepis were found [80], while the protozoa found were Eimeria trinidadensis, E. ichiloensis, and E. boliviensis [81]. A more detailed study in Venezuela found a negative association between the body condition and helminth intensity for M. macrobursatum (found in the small intestine), V. hydrochoeri (small intestine), and H. hippocrepis (large intestine) [82]. Other parasites found were Monoecocestus hagmanni (small intestine), Protozoophaga obesa (cecum), Taxorchis schistocotyle (cecum), Hippocrepis hippocrepis, Eimeria trinidadensis, E. ichiloensis, and E. boliviensis [81,82]. In Columbia, the following protozoan parasites were identified: Sarcocystis spp., Eimeria spp., Giardia spp., Cycloposthium hydrochaeri, C. incurvum, C. minutum, C. lenticularis, and C. compressum [83].

Stress by feed restriction and physical restraint had a negative effect on growth and body condition and induced a significantly higher coccidia infestation, and a lower helminth burden showing that the living conditions may have an influence on parasitic infestation [84]. Environmental conditions such as season, age, and sex of the animals have also been associated with different parasitic infestations. This shows that the interactions amongst gastrointestinal parasites are complex and further research is needed [85].

Capybaras have been shown to have a wide range of endoparasites, but they appear largely resistant to their effects and show only a few signs of ill health [86]. The capybaras, being the largest rodents on earth, have been given a lot of attention. However, the majority of investigations only noted the presence or absence of endoparasites without making observations on the effects these organisms had on the animals (Table 3). 
Table 3. Endoparasites found in the Capybara (Hydrochoeris hydrochaeris) at different locations.

\begin{tabular}{|c|c|c|c|c|c|}
\hline Parasite & Location & Effect on Animal Health or Pathological Lesion & Diagnosis & Year & Ref. \\
\hline Taxorchis schistocotyle & Panama & No lesions were observed in the intestinal tract & Necropsy and microscopy & 1935 & [57] \\
\hline Balantidium coli & Florida & $\begin{array}{l}\text { Ulceration on colon with infiltration of plasma cells, } \\
\text { eosinophils and macrophages }\end{array}$ & Necropsy and histology & 1961 & [58] \\
\hline Taxorchis schostocotyle, Protozoophaga obesa & Brazil & Not recorded & Necropsy and microscopy & 2016 & [35] \\
\hline $\begin{array}{c}\text { Cruorifilaria tuberocauda, Eucoleus hydrochoeri, Echinocoleus hydrochaeri, } \\
\text { Habronema clarki, Hydrochoerisnema anomalobursata, Protozoophaga obesa, } \\
\text { Strongyloides chapini, Trichostrongylus axei, Vianella hydrochoeri, Yatesia } \\
\text { hydrochoerus }\end{array}$ & Brazil & Not recorded & Necropsy and microscopy & 1997 & [27] \\
\hline $\begin{array}{c}\text { Trichostrongylus axei, Vianella hydrochoeri, Strongyloides chapini, Yatesia } \\
\text { hydrochoerus, Cruorifilaria tubercauda, Capillaria hydrochoeri, Protozoophaga obesa, } \\
\text { Taxorchis schistocotyle, Hippocrepis hippocrepis, Nudacotyle tertius, Monoecocestus } \\
\text { hydrochoeri, Monoecocestus hagmanni }\end{array}$ & Brazil & Not recorded & Necropsy and microscopy & 1994 & [69] \\
\hline $\begin{array}{c}\text { Monoecocestus hagmanni, M. hydrochoeri, M. macrobursatum, Habronema clarki, } \\
\text { Vianella hydochoeri, Protozoophaga obesa, Taxorchis schistocotyle, Hippocrepis } \\
\text { hippocrepis }\end{array}$ & Bolivia & Not recorded & Necropsy and microscopy & 1995 & [80] \\
\hline Eimeria trinidadensis, E. ichiloensis, E. boliviensis & Bolivia and Venezuela & Not recorded & Necropsy and microscopy & 1995 & [81] \\
\hline $\begin{array}{l}\text { Protozoophaga obesa, Viannella hydrochoeri, Hydrochoerisnema anomalobursata, } \\
\text { Taxorchis schistocotyle, Hippocrepis hippocrepis, Capillaria hydrochoeri, } \\
\text { Strongyloides chapini, Monoecocestus macrobursatum, M. hydrochoeri, M. hagmani, } \\
\text { Trichostrongylus axei, Neocotyle neocotyle, Nudacotyle valdevaginatus, N. tertius }\end{array}$ & Brazil & Not recorded & Necropsy and microscopy & 2002 & [62] \\
\hline $\begin{array}{c}\text { Stongyloides spp., Habronema spp., Capillaria hysrochoeri, Vianella hydrochoeri, } \\
\text { Protozoophaga obesa, Taxorchis schistocotyle, Hydrochoeristrema cabrali, } \\
\text { Monoecocestus hydrochoeris, Monoecocestus hagmani }\end{array}$ & Brazil & Not recorded & Necropsy and microscopy & 2004 & [70] \\
\hline $\begin{array}{c}\text { Eimeria spp., Blastocystis spp., Balantidium coli, Ascaridia, Trichostrongylidae, } \\
\text { Protozoophaga obesa, Strongyloides spp., Capillaria hydrochoaeri, Monoecocestus } \\
\text { hydrochoeri, Taxorchis schistocotyle }\end{array}$ & Argentina & Not recorded & $\begin{array}{l}\text { Fecal floatation and } \\
\text { sedimentation }\end{array}$ & 2011 & [76] \\
\hline Echinocoleus hydrochoeri & Argentina & Not recorded & Necropsy and microscopy & 2013 & [78] \\
\hline Protozoophaga spp., Vianella spp., Strongyloides spp., Ancylostomatidae & Brazil & $\begin{array}{l}\text { Haematology and serum biochemistry showed a mild } \\
\text { mal-nutrition and parasitism but no overt clinical } \\
\text { signs were seen }\end{array}$ & Fecal floatation & 2014 & [75] \\
\hline $\begin{array}{l}\text { Sarcocystis spp., Eimeria spp., Giardia spp., Cycloposthium hydrochaeri, C. } \\
\text { incuroum, C. minutum, C. lenticularis, C. compressum }\end{array}$ & Columbia & Not recorded & $\begin{array}{l}\text { Fecal floatation, fecal } \\
\text { sedimentation }\end{array}$ & 2015 & [83] \\
\hline $\begin{array}{l}\text { Hippocrepis hippocrepis, H. fuelleborni, Philophthalmus lachrymosus, Taxorchis } \\
\text { schistocotyle, Monoecocestus macrobursatus, M. hydrochaeri, Monoecocustus spp., } \\
\text { Anoplochephalidae, Protozoophaga obesa, Strongyloides spp. }\end{array}$ & Brazil & Not recorded & Necropsy and microscopy & 2015 & [66] \\
\hline $\begin{array}{c}\text { Capillaria hydrochoeri, Hydrochoerisnema anomalobursata, Monoecocestus } \\
\text { hagmanni, M. macrobursatum, Protozoophaga obesa }\end{array}$ & Brazil & Not recorded & Necropsy and microscopy & 2016 & [71] \\
\hline Fasciola hepatica, Capillaria spp. & Brazil & Not recorded & Coproscopy & 2018 & [68] \\
\hline Trichuris cutillasae & Argentina & Not recorded & $\begin{array}{c}\text { Molecular and } \\
\text { Morphological techniques }\end{array}$ & 2019 & [79] \\
\hline
\end{tabular}




\section{Manicou (Didelphis marsupialis insularis/Didelphis marsupialis)}

The earliest data on endoparasites of the manicou (D. marsupialis insularis) were recorded in the early 1950s in Trinidad. In the large intestine, Aspidodera raillieti, Sublura trinitatis, Trichuris reesali, Trichuris minuta Trichuris urichi, Cruzia cameroni, Longistriata didelphis, and Viannnaia hamata were identified. In the small intestine, Fuellebornema agouti, Delicata spp., Camerostrongylus didelphis, and Capillaria spp. were recorded. Physaloptera turgida and Spirocerca cylicola (later found to be Didelphonema longispiculata [87]) were found in the stomach and small intestine. While, Helminthoxys urichi was found in the stomach [88]. The trematodes Achillurabainia recondita and Rhopalias coronatus were found in the intestines and Metadelphis evandroi was found in the bile duct [89].

In the US (Alabama and Georgia), Isospora boughtoni and Isospora spp. oocysts, Brachylaima virginianum, and Cruzia americana were found in the intestines of opossum (D. marsupialis) [90]. Phyaloptera turgida was found in the stomach and ulcerations penetrated from the glandular mucosa to the submucosal level [91]. In the lung, Capillaria aerophila and metastrongyloid nematodes which resembled Perostrongylus and Didelphostrongylus hayesi were found [91,92]. The lungs infested with Perostrongylus showed a diffuse interstitial pneumonia pattern [91].

In Brazil, two hundred and twenty-four D. marsupialis were examined and fifteen animals were found with Besnoitia spp. in cystic leasions in the muscles and viscera [93]. Other parasites detected in Brazil were Capillaria spp. (palate), Eucoleus fluminensis (mouth), Trichuris minuta (large intestine), Heterostrongylus spp. (lungs), Mammomonogamus laryngeus (nostrils), and Aspidodera raillieti (large intestine). Aspidodera spp., Cruzia tentaculata, Turgida turgida (stomach), Thelazia iheringi, Dipetalonema spp. (liver cysts, peritoneum, skin), Litomosoides spp. (skin), Lagochilascaris turgida, Viannaia hamata, and Sarcocystis neurona [26,27]. S. neurona caused neurological diseases in different animal species and is also zoonotic [94]. Similar endoparasites that were found in D. marsupialis in Brazil were also found in Peru [95].

In Costa Rica, the coccidian, Eimeria marmosopos, was found [96], and this coccidial species was located in the epithelial cell of the small intestines and caused cellular necrosis [97]. Recently in Mexico, the gall bladder was found to be the site of infection for Amphimerus caudaletestis and Philandrophilus magnacirrus. In the intestines, Rhopalias coronatus, $R$. macracanthus, Thaumasioscolex didelphidis, Viannaia viannai, Travassostrongylus spp., and Onicola luehei were found and the cecum was the predilection site for Cruzia tentaculata and Trichuris didelphis. Turgida turgida was found in the stomach and Capillaria spp. was found in the lungs [98]. Aspidodera spp. and C. tentaculata were found in the small intestines of D. marsupialis in Pocone, Brazil [35] (Table 4). 
Table 4. Endoparasites found in the Manicou (Didelphis marsupialis insularis/D. marsupialis) at different locations.

\begin{tabular}{|c|c|c|c|c|c|}
\hline Parasite & Location & $\begin{array}{l}\text { Effect on Animal Health or } \\
\text { Pathological Lesion }\end{array}$ & Diagnosis & Year & Ref \\
\hline $\begin{array}{c}\text { Aspidodera raillieti, Sublura trinitatis, Trichuris reesali, Trichuris } \\
\text { minuta Trichuris urichi, Cruzia cameroni, Longistriata didelphis, } \\
\text { Viannnaia hamata, Fuellebornema agouti, Delicata spp., } \\
\text { Camerostrongylus didelphis, Capillaria spp., Physaloptera turgida, } \\
\text { Spirocerca cylicola, Helminthoxys urichi }\end{array}$ & Trinidad & Not recorded & Necropsy and microscopy & 1951 & {$[88]$} \\
\hline Didelphonema longispiculata (syn. Spirocerca cylicola) & Trinidad & Not recorded & Necropsy and microscopy & 1953 & [87] \\
\hline Achillurabainia recondita, Rhopalias coronatus, Metadelphis evandroi & Trinidad & Not recorded & Necropsy and microscopy & 1958 & [89] \\
\hline Isospora boughtoni, Isospora spp. & Alabama & Not recorded & Sedimentation techniques & 1969 & {$[90]$} \\
\hline $\begin{array}{l}\text { Phyaloptera turgida, Brachylaima virginianum, Cruzia americana, } \\
\text { Capillaria aerophilia, Perostrongylus spp. }\end{array}$ & Georgia & $\begin{array}{l}\text { Weak, emaciated, circling and } \\
\text { uncoordinated }\end{array}$ & Necropsy and microscopy & 1975 & [91] \\
\hline Didelphostrongylus hayesi & Georgia & Not recorded & Necropsy and microscopy & 1976 & [92] \\
\hline Besnoitia spp. & Brazil & Not recorded & Necropsy and Histology & 1983 & [93] \\
\hline $\begin{array}{c}\text { Aspidodera raillieti, Cruzia tentaculata, Lagochilascaris turgida, } \\
\text { Viannaia hamata }\end{array}$ & Brazil & Not recorded & Microscopy & 1997 & {$[27]$} \\
\hline $\begin{array}{l}\text { Capillaria spp., Eucoleus fluminensis, Trichuris minuta, } \\
\text { Heterostrongylus spp., Mammomonogamus laryngeus, Aspidodera } \\
\text { raillieti, Aspidodera spp., Cruzia tentaculata, Turgida turgida, } \\
\text { Thelazia iheringi, Dipetalonema spp., Litomosoides spp. }\end{array}$ & Brazil & Not recorded & Necropsy and Microscopy & 2002 & {$[26]$} \\
\hline Eimeria marmosopos & Costa Rica & Not recorded & $\begin{array}{l}\text { Fecal floatation and } \\
\text { microscopy }\end{array}$ & 2015 & [96] \\
\hline E. marmosopos $\left(1 \times 10^{5}\right.$ oocyst/gram $)$ & Costa Rica & $\begin{array}{l}\text { Necrosis of cells of the small } \\
\text { intestine }\end{array}$ & Histology & 2015 & [97] \\
\hline $\begin{array}{c}\text { Amphimerus caudaletestis, Philandrophilus magnacirrus, Rhopalias } \\
\text { coronatus, R. macracanthus, Thaumasioscolex didelphidis, Viannaia } \\
\text { viannai, Travassostrongylus spp., Onicola luehei, Cruzia tentaculata, } \\
\text { Trichuris didelphis, Turgida turgida, Capillaria spp. }\end{array}$ & Mexico & Not recorded & Necropsy and Microscopy & 2015 & {$[98]$} \\
\hline Aspidodera spp., Cruzia tentaculata & Brazil & Not recorded & Necropsy and microscopy & 2016 & {$[35]$} \\
\hline
\end{tabular}




\section{Collared Peccary (Pecari tajucu/Tayassu tajacu)}

The earliest study on parasites in peccaries was done in the 1930s in Texas and Moneizia bendeni and Parostertagia heterospiculum was found in the small intestine [99]. In the stomach, Physocephalus sexalatus was found and in the oesophagus, Parabronema spp. [99,100]. Much later and in the same region, Eimeria chaparralensis, Eimeria dicotylensis, Eimeria pecari, Eimeria spp., Klossia spp., Balantidium spp., Dirofilaria acutiuscula, Gongylonema baylisi, Gongylonema pulchrum, Physocephalus sexalatus, Parabronema pecariae (Stomach), Parostertagia heterospiculum, Physocephalus spp., Texicospirura turki, Moniezia benedeni, and Fascioloides magna were found [101-105], while another study failed to recover endoparasites [106]

In Brazil, in the late 1930s, Gonglyonema baylisi was found in the oesophagus [107] and later on Texicospiruria turki, Parabronema pecariae, Physocephalus sexalatus, Gongylonema spp., and Gongylonema baylisi detected in the stomach. Monodontus semicircularis and Moniezia benedeni in the small intestine; Eucyathostomum dentatum, Trichuris spp., and Balantidium coli in the large intestine; and Dirofilaria acutiuscula, Molineus semicircularis, Nematodirus molina, and Oesophagostomumdentatum [27,108,109]. In Peru, eggs of Ascaris spp., ancylostomatids, spirurids, Paragonimus spp., Giardia spp., Cryptosporidium spp., Balantidium spp., and Eimeria spp. were identified in the fecal samples $[110,111]$. It should be noted that Cryptosporidium spp. and Giardia spp. are of zoonotic importance (Table 5).

In Surinam, Toxocara alienata were found but was not associated with poor body condition [112]. In Mexico, Globocephalus urosubulatus, Parabronema pecariae, Parostertagia spp., Texicospiruria turki, and Paramphistomum spp. were detected in the stomach and Oesophagostomum spp. Strongyloides spp., Eimeria spp., Isospora spp., Oesophagostomum spp., and Moniezia benedeni inhabited the intestines [113,114]. In Panama, Entamoeba coli, Entamoeba spp., Cryptosporidium spp., Endolimax nana, and Strongyloides spp. were detected [115]. In Bolivia, Texicospiruria turki, Monodontus angulari, Eucyathostomum spp., Stichorchis giganteus, Moniezia benedeni, Ascaris spp., and Eimeria spp. were detected [116]. In the work done in mid 1980s by Hellgren et al. [117] on collared peccaries with signs of respiratory distress and coughing, Ascaris suum was found in the bile duct and the same parasite was found in South America [117-119]. 
Table 5. Endoparasites found in the collared peccary (Tayassu tajacu) at different locations.

\begin{tabular}{|c|c|c|c|c|c|}
\hline Parasite & Location & $\begin{array}{l}\text { Effect on Animal Health or } \\
\text { Pathological Lesion }\end{array}$ & Diagnostics & Year & Ref. \\
\hline Moneizia bendeni & Texas & Not recorded & Necropsy & 1931 & [99] \\
\hline Physocephalus sexalatus, Moniezia benedeni, Parostertagia heterospiculum & Texas & Not recorded & Necropsy & 1933 & {$[100]$} \\
\hline Texicospirura turki & Texas and New Mexico & Not recorded & Necropsy & 1966 & {$[110]$} \\
\hline $\begin{array}{c}\text { Balantidium spp., Dirofilaria acutiuscula, Gongylonema baylisi, Parabronema } \\
\text { pecariae, Parostertagia heterospiculum, Physocephalus spp., Texicospirura } \\
\text { turki, Moniezia benedeni, Fascioloides magna }\end{array}$ & Texas & Not recorded & Necropsy & 1970 & {$[101]$} \\
\hline $\begin{array}{c}\text { Gongylonema pulchrum, Parabronema pecariae, Texicospirura turki, } \\
\text { Physocephalus sexalatus and Moniezia benedeni }\end{array}$ & Texas & $\begin{array}{l}\text { No evidence of disease or loss of } \\
\text { body condition }\end{array}$ & Necropsy & 1985 & {$[102]$} \\
\hline $\begin{array}{l}\text { Eimeria chaparralensis, Eimeria dicotylensis, Eimeria pecari, Eimeria spp., } \\
\text { Klossia spp. }\end{array}$ & Texas & Not recorded & Fecal floatation & 1996 & {$[103$} \\
\hline Ascarid suum & Texas & Respiratory distress and coughing & Necropsy & 1984 & [117] \\
\hline Parabronema peccariae, Trichostrongylus columbiformis & Mexico & Not recorded & Necropsy & 1968 & {$[105$} \\
\hline $\begin{array}{c}\text { Globocephalus urosubulatus, Parabronema pecariae, Parostertagia spp., } \\
\text { Texicospiruria turki, Paramphistomum spp., Oesophagostomum spp., } \\
\text { Moniezia benedeni }\end{array}$ & Mexico & Not recorded & $\begin{array}{l}\text { Fecal floatation, sedimentation and } \\
\text { necropsy }\end{array}$ & 2008 & {$[113]$} \\
\hline Gonglyonema baylisi & Brazil & Not recorded & Necropsy & 1937 & {$[107]$} \\
\hline $\begin{array}{l}\text { Dirofilaria acutiuscula, Eucyathostomum dentatum, Gongylonema baylisi, } \\
\text { Molineus semicircularis, Nematodirus molina, Oesophagostomum dentatum }\end{array}$ & Brazil & Not recorded & Necropsy & 1997 & [27] \\
\hline Strongyloides spp., Eimeria spp., Isospora spp., Oesophagostomum spp. & Brazil & Not recorded & $\begin{array}{l}\text { Fecal centrifugation floatation and } \\
\text { Mc Master Technique }\end{array}$ & 2014 & {$[114]$} \\
\hline $\begin{array}{l}\text { Texicospiruria turki, Monodontus angulari, Eucyathostomum spp., Stichorchis } \\
\text { giganteus, Moniezia benedeni, Ascaris spp., Eimeria spp. }\end{array}$ & Bolivia & Not recorded & Fecal floatation and sedimentation & 2014 & {$[116]$} \\
\hline $\begin{array}{l}\text { Entamoeba coli, Entamoeba spp., Cryptosporidium spp., Endolimax nana, } \\
\text { Strongyloides spp. }\end{array}$ & Panama & Not recorded & Fecal centrifugation floatation & 2010 & {$[115]$} \\
\hline Ascaris spp., ancylostomatids, spirurid, Paragonimus spp. & Peru & Not recorded & $\begin{array}{l}\text { Fecal floatational and } \\
\text { sedimentation }\end{array}$ & 2008 & {$[110]$} \\
\hline $\begin{array}{l}\text { Texicospiruria turki, Parabronema pecariae, Physocephalus sexalatus and } \\
\text { Gongylonema spp., Monodontus semicircularis, Moniezia benedeni, } \\
\text { Eucyathostomum dentatum, Trichuris spp., Balantidium coli }\end{array}$ & Central Amazon & Not recorded & Necropsy & 1986 & {$[108$} \\
\hline Toxocara alienate & Surinam & Not recorded & Necropsy & 1982 & {$[112$} \\
\hline Giardia spp., Cryptosporidium spp., Balantidium spp., Eimeria spp. & Brazil & Not recorded & Fecal floatation & 2010 & [111] \\
\hline
\end{tabular}




\section{Red Brocket Deer (Mazama americana)}

In Trinidad, in the 1930s, Mazama simplicicornis was found to have the following parasites; Mazamanema longibursatum, Ierestrongylus filiformis, Mazamastrongylus trinitatis, Paramphistomum cotylophorum, Moniezia benedeni, Setaria bidentata, Eucyathostomum longesubulatum, Strongyloides papillosus, and Nematodirus urichi. Setaria bidentate was found in the omentum, and Eucyathostomum longesubulatum and an oxyurid-type worm was found in the large intestine [120-122]. In Brazil, parasites found in Mazama americana were Dictyocaulus spp., Eucyathostomum spp., Eucyathostomum longibursatum, Seteria bidentate, Seteria spp. Haemonchus contortus, Haemonchus similis, Trichostrongylus axei, Trichostrongylus colubriformis, Physocephalus sexulatus, P. lassencei, Pygarginema verrucosa, Paramphistomum spp., Eimeria spp., and Cooperia punctata [27,61,123,124] (Table 6). Lux Hoppe et al. [125] found Trichostrongylus axei, Haemonchus contortus, H. similis, Physocephalus lassancei, and Pygarginema verrucosa in the abomasum. Capillaria bovis, Bunostomum phlebotomum, and Cooperia punctata inhabited the small intestine.

Table 6. Endoparasites found in the Red Brocket deer (Mazama americana) at different locations.

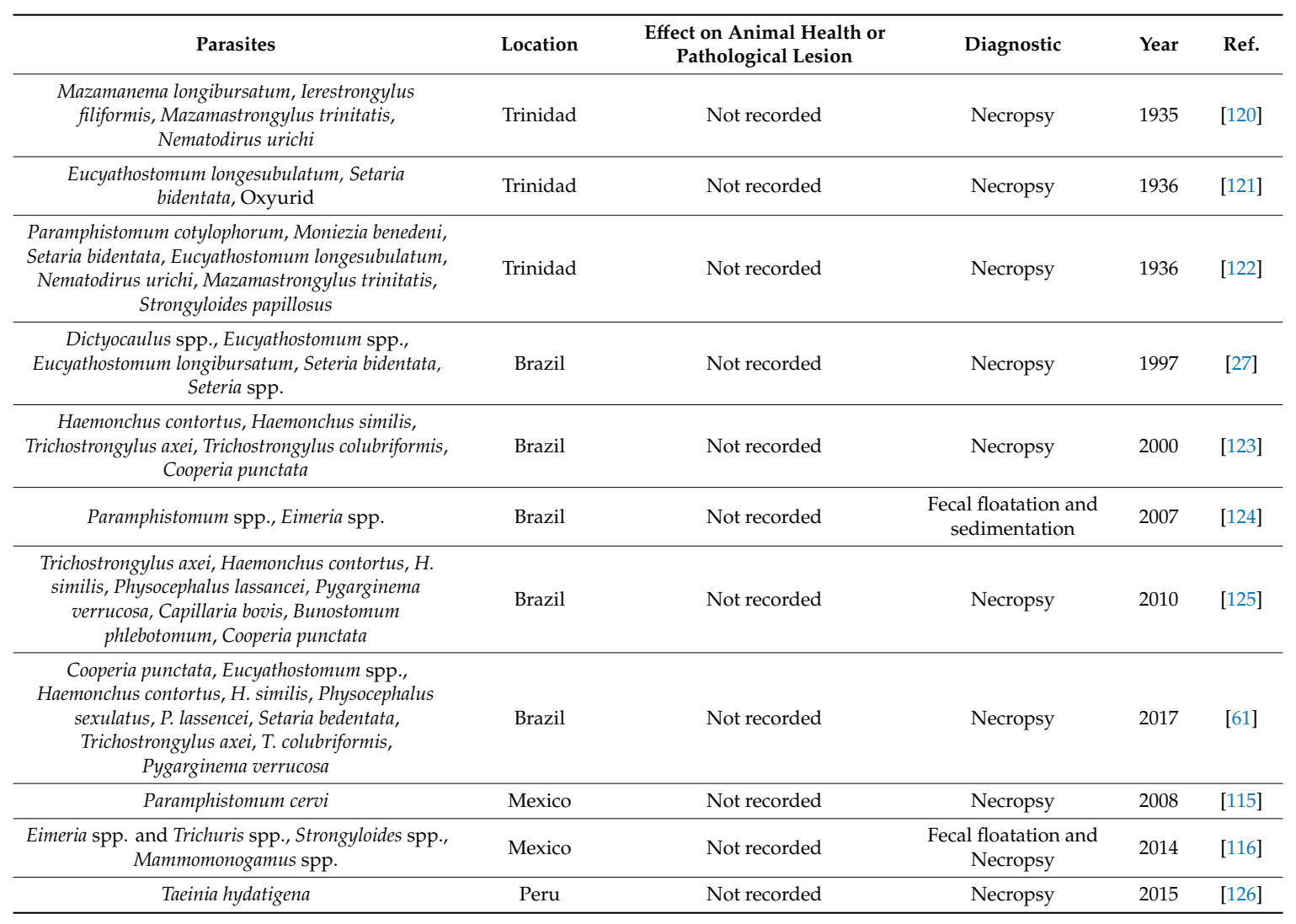

In Mexico, Paramphistomum cervi was found in the rumen and abomasum as well as Eimeria spp., Trichuris spp., Strongyloides spp., and Mammomonogamus spp. [115,116] (Table 6). In Peru, the cysticercus of Taenia hydatigena was found in the omentum of M. americana as an intermediate host, while the definitive hosts were identified as carnivores [126]. A summary of endoparasites found in specific neo-tropical host species was provided (Table 7). Endoparasites that were common to different animal (host) was also listed (Table 7). 
Table 7. Endoparasites found in selected non-domesticated neotropical animals.

\begin{tabular}{|c|c|c|c|}
\hline Neotropical Animals Species (Hosts) & $\begin{array}{l}\text { Total No. of Internal Parasites } \\
\text { Reported }\end{array}$ & Endoparasites Found in the Six Selected Host Species & $\begin{array}{l}\text { Similar Endoparasites Found in Various } \\
\text { Neotropical Animal Host Species }\end{array}$ \\
\hline Agouti (D. leporina) & 29 & $\begin{array}{c}\text { Strongyloides spp., Stichorchis giganteus, Raillietina demerariensis var. trinitatae, } \\
\text { Strongyloides agouti, Trichuris gracilis var. trinitatae, Trichuris spp., } \\
\text { Acanthocheilonema spp., Fuellebornema agouti, Pudica pudica, Aspidodera binansata } \\
\text { var. agouti, Helminthoxys urichi, Paraspidodera uncinata, Pudica gonosoma, } \\
\text { Durettestrongylus baudi, Fuellebornema granulosa, Fuellebornema demarsae, } \\
\text { Eucyathostomum copulatum, Physocephalus meridonalis, Physocephalus torresi, } \\
\text { Physocephalus mediospiralis, Diptalonema spp., Vianella trichospicula, Avellaria } \\
\text { intermedia, Eimeria aguti, Eimeria cotiae, Eimeria paraensis, Eimeria spp., Giardia } \\
\text { spp., Echinococcus oligarthrus, Freitastrongylus angelae }\end{array}$ & $\begin{array}{c}\text { Helminthoxys urichi (manicou and agouti) } \\
\text { Paraspidodera uncinata, Trichuris spp., } \\
\text { Strongyloides spp., Physocephalus meridonalis, } \\
\text { Eimeria agouti, Raillietina demarariensis, Eimeria } \\
\text { spp., (agouti and lappe) }\end{array}$ \\
\hline Lappe (A. paca) & 24 & $\begin{array}{c}\text { Heligmostrongylus sedecimradiatus, Heligmostrongylus agouti, Longistriata } \\
\text { breviscapula, Oswaldonema cruzi, Oswaldonema skrjabini, Paraspidodera uncinata, } \\
\text { Paraspidodera spp., Pereiraia spp., Turgida torresi, Trichuris spp., Vianella avellari, } \\
\text { Strongyloides spp., Strongylus spp., Physocephalus meridonalis, Echinococcus } \\
\text { vogeli, Coladium hepaticum, Physocephalus spp., Eimeria spp., Hymenolepis } \\
\text { diminuta, Eimeria agouti, Capillaria spp., Taenia spp., Raillietina demarariensis, } \\
\text { Echinococcus spp. }\end{array}$ & $\begin{array}{l}\text { Strongyloides spp., Giardia spp., Eimeria spp. } \\
\text { (agouti, lappe, capybara, and collared peccary) }\end{array}$ \\
\hline Capybara (H. hydrochaeris) & 42 & $\begin{array}{l}\text { Taxorchis schistocotyle, Balantidium coli, Protozoophaga obesa, Cruorifilaria } \\
\text { tuberocauda, Eucoleus hydrochoeri, Echinocoleus hydrochaeri, Habronema clarki, } \\
\text { Habronema spp., Hydrochoerisnema anomalobursata, Strongyloides chapini, } \\
\text { Strongyloides spp., Trichostrongylus axei, Vianella hydrochoeri, Vianella spp., } \\
\text { Yatesia hydrochoerus, Hippocrepis hippocrepis, Hippocrepis fuelleborni, } \\
\text { Philophthalmus lachrymosus, Neocotyle neocotyle, Nudacotyle valdevaginatus, } \\
\text { Nudacotyle tertius, Monoecocestus hydrochoeri, Monoecocestus hagmanni, } \\
\text { Monoecocestus macrobursatum, Monoecocestus spp., Eimeria trinidadensis, Eimeria } \\
\text { ichiloensis, Eimeria boliviensis, Eimeria spp., Blastocystis spp., Sarcocystis spp., } \\
\text { Giardia spp., Cycloposthium hydrochaeri, Cycloposthium incurvum, Cycloposthium } \\
\text { minutum, Cyclposthium lenticularis, Cycloposthium compressum, Fasciola hepatica, } \\
\text { Capillaria spp., Trichuris cutillasae }\end{array}$ & $\begin{array}{l}\text { Trichostongylus columbiformis, Strongyloides spp., } \\
\text { Eimeria spp., Physocephalus sexulatus, Trichuris } \\
\text { spp., Moniezia benedeni, Paramphisotmum spp. } \\
\text { (capybara and red brocket deer) } \\
\text { Capillaria spp. (capybara and manicou) } \\
\text { Balantidium coli, Giardia spp., (common to } \\
\text { capybara and collared peccary) }\end{array}$ \\
\hline Manicou (D. marsupialis insularis) & 44 & $\begin{array}{l}\text { Aspidodera raillieti, Aspidodera spp., Sublura trinitatis, Trichuris reesali, Trichuris } \\
\text { minuta, Trichuris urichi, Trichuris didelphis, Cruzia cameroni, Cruzia americana, } \\
\text { Cruzia tentaculata, Longistrata didelphis, Viannaia hamata, Viannaia viannai, } \\
\text { Fuellebornema agouti, Delicata spp., Travassostrongylus spp., Camerostrongylus } \\
\text { didelphis, Capillaria aerophilia, Capillaria spp., Physaleptera turgida, Spirocerca } \\
\text { cylicola, Helminthoxys urichi, Achillurabainia recondite, Rhopalias coronatus, } \\
\text { Metadelphis evandroi, Isospora boughtoni, Isospora spp., Brachylaima virginianum, } \\
\text { Perostrongylus spp., Heterostrongylus spp., Didelphostrongylus hayesi, Besnoitia } \\
\text { spp., Lagochilascaris turgida, Eucoleus fluminensis, Mammomonogamus laryngeus, } \\
\text { Turgida turgida, Thelazia iheringi, Diptalonema spp., Litomosoides spp., Eimeria } \\
\text { marmosopos, Amphimerus caudaletestis, Philandrophilus magnacirrus, } \\
\text { Thaumasioscolex didelphidis, Onicola luehei }\end{array}$ & $\begin{array}{l}\text { Trichostongylus columbiformis, Strongyloides spp., } \\
\text { Eimeria spp., Physocephalus sexulatus, Trichuris } \\
\text { spp., Moniezia benedeni, Paramphisotmum spp. } \\
\text { (capybara and red brocket deer) } \\
\text { Capillaria spp. (capybara and manicou) } \\
\text { Balantidium coli, Giardia spp., (common to } \\
\text { capybara and collared peccary) }\end{array}$ \\
\hline
\end{tabular}


Table 7. Cont.

\begin{tabular}{|c|c|c|c|}
\hline Neotropical Animals Species (Hosts) & $\begin{array}{c}\text { Total No. of Internal Parasites } \\
\text { Reported }\end{array}$ & Endoparasites Found in the Six Selected Host Species & $\begin{array}{c}\text { Similar Endoparasites Found in Various } \\
\text { Neotropical Animal Host Species }\end{array}$ \\
\hline Collared peccary (T. tajacu) & 39 & $\begin{array}{c}\text { Moniezia benedeni, Physocephalus sexalatus, Physocephalus spp., Parostertagia } \\
\text { heterospiculum, Texicospirura turki, Balantidium coli, Dirofilaria acutiuscula, } \\
\text { Gongylonema baylisi, Gongylonema pulchrum, Parabronema pecariae, Fascioloides } \\
\text { magna, Eimeria chaparrelensis, Eimeria dicotylensis, Eimeria pecari, Eimeria spp., } \\
\text { Isospora spp., Klossia spp., Ascaris suum, Ascaris spp., Trichostrongylus } \\
\text { columbiformis, Globocephalus urosubulatus, Paramphistomum spp., } \\
\text { Oesophagostomum spp., Oesophagostomum dentatum, Nematodirus molina, } \\
\text { Eucyathostomum dentatum, Eucyathostomum spp., Stichorchis giganteus, Molineus } \\
\text { semicircularis, Strongyloides spp., Paragonimus spp., Monodontus angularis, } \\
\text { Entamoeba coli, Entamoeba spp., Cryptosporidium spp., Endolimax nana, Trichuris } \\
\text { spp., Toxocara alienata, Giardia spp. }\end{array}$ & $\begin{array}{l}\text { Trichurs spp., Strongyloides spp., Eimeria spp., } \\
\text { Giardia spp., Stichorchis giganteus (agouti and } \\
\text { collared peccary) }\end{array}$ \\
\hline Red Brocket deer (M. americana) & 30 & $\begin{array}{l}\text { Mazamanema longibursatum, Ierestrongylus filiformis, Mazamastrongylus trinitatis, } \\
\text { Nematodirus urichi, Eucyathostomum longesubulatum, Eucyathostomum spp., } \\
\text { Setaria bidentata, Setaria spp., Paramphistomum cotylophorrum, Paramphistomum } \\
\text { cervi, Paramphistomum spp., Moniezia benedeni, Strongyloides papillosus, } \\
\text { Strongyloides spp., Dictyocaulus spp., Haemonchus contortus, Haemonchus similis, } \\
\text { Trichostrongylus axei, Trichostrongylus columbiformis, Cooperia punctata, Eimeria } \\
\text { spp., Physocephalus lassancei, Physocephalus sexalatus, Pygarginema verrucosa, } \\
\text { Capillaria bovis, Bunostomum phlebotomum, Trichuris spp., Taenia spp., } \\
\text { Mammomonogamus spp. }\end{array}$ & $\begin{array}{l}\text { Trichuris spp., Strongyloides spp., Eimeria spp. } \\
\text { (agouti and red brocket deer) } \\
\text { Strongyloides spp., Eimeria spp. (lappe and red } \\
\text { brocket deer) }\end{array}$ \\
\hline
\end{tabular}




\section{Conclusions}

Most endoparasites were detected (clinical or subclinical) in the agouti, while for the red brocket deer (Mazama americana) few endoparasites were found (Table 7). This was in relation to the number of studies performed on these animals. A large majority of the authors viewed these neotropical non-domesticated animals as parasitic reservoirs that could affect domesticated introducted livestock species. The endoparasites of zoonotic significance found in the non-domesticatic neotropical animals were Echinoccocus spp., Trichuris spp., Giardia spp., and Cryptosporidium spp. There were a few reports of parasites showing negative effects on neotropical non-domesticated animals. Further studies on the effect of parasitism on these six neotropical species should elucidate their importance as pathogens, and their effect on the growth and performance of animals. Furthermore, the relation between the infestation grade and clinical manifestation should be deteremined.

Author Contributions: K.R.J. conceptualized and collected the literature for the composition of the draft document. G.W.G. and K.R.L. made revisions to the draft document. G.W.G. supervised the entire project.

Funding: This project was funded by the Campus Research and Publication Fund at the University of the West Indies, St. Augustine Campus.

Acknowledgments: Staff at the Alma Jordan Library, University of the West Indies St, Augustine Campus.

Conflicts of Interest: There authors declare no conflict of interest.

\section{References}

1. Jones, K.R.; Garcia, G.W. Gastrointestinal parasites of domesticated animals introduced into the Neo-tropics (New World Tropics). Concept. Dairy Vet. Sci. 2018, 1, 51-67. Available online: https://www.lupinepublishers. com/cdvs/pdf/CDVS.MS.ID.000110.pdf (accessed on 15 March 2019).

2. Jones, K.R.; Garcia, G.W. Endoparasites of domesticated animals that originated in the neo-tropics (new world tropics). Vet. Sci. 2019, 6, 24. [CrossRef] [PubMed]

3. Brown-Uddenberg, R.; Garcia, G.W.; Baptiste, Q.S.; Counand, T.; Adogwa, A.; Sampson, T. The Agouti (Dasyprocta leporina, D. agouti) Booklet and Production Manual. 2004. St. Augustine, Trinidad: GWG Publications, 24 Sagan Drive, Champs Fleur. Website: The Open School of Tropical Animal Science and Production. Available online: http://www.ostasp.brinkster.net (accessed on 15 April 2019).

4. Garcia, G. Intensification of Animal Production systems for improving wildlife conservation. In Agriculture in the Caribbean, Issues and Challenges; University of the West Indies: Port of Spain, Trinidad and Tobago, 1999; Volume 3, pp. 89-99.

5. Mollineau, W.M.; Sampson, T.; Adogwa, A.O.; Garcia, G.W. Anatomical stages of penile erection in the agouti (Dasyprocta leporina) induced by electro-ejaculation. Anat. Histol. Embryol. 2012, 41, 392-394. [CrossRef] [PubMed]

6. Mollineau, W.M.; Adogwa, A.O.; Garcia, G.W. Spermatozoal morphologies and fructose and citric acid concentrations in agouti (Dasyprocta leporina) semen. Anim. Reprod. Sci. 2008, 105, 378-383. [CrossRef]

7. Guimaraes, D.A.; Ramos, R.L.; Ohashi, O.M.; Garcia, G.W.; Vale, W.G. Plasma concentration of progesterone and $17 \beta$-estradiol of black-rumped agouti (Dasyprocta leporina) during the estrous cycle. Rev. Biol. Trop. 2011, $59,29-35$.

8. Singh, M.D.; Adogwa, A.O.; Mollineau, W.M.; Garcia, G.W. Gross and microscopic anatomy of the reproductive tract of the female agouti (Dasyprocta leporina): A Neo-tropical rodent with potential for food production. Trop. Agric. (Trinidad) 2014, 9, 38-46.

9. Garcia, G.W.; Baptiste, Q.S.; Adogwa, A.O.; Kakuni, M.; Arishima, K.; Makita, T. The Digestive System of the Agouti (Dasyprocta leporina)-Gross Anatomy and Histology. Jpn. J. Zoo Wildl. Med. 2000, 5, 55-66. [CrossRef]

10. Henry, O. Frugivory and the Importance of Seeds in the Diet of the Orange-Rumped Agouti (Dasyprocta leporina) in French Guiana. J. Trop. Ecol. 1999, 15, 291-300. [CrossRef]

11. Silvius, K.M.; Fragoso, J.M.V. Red-rumped agouti (Dasyprocta leporina) home range use in an Amazonian forest: Implications for the aggregated distribution of forest trees. Biotropica 2003, 35, 74-83. [CrossRef]

12. Lall, K.R.; Jones, K.R.; Garcia, G.W. Nutrition of six selected neotropical mammals in Trinidad and Tobago with the potential for domestication. Vet. Sci. 2018, 5, 52. [CrossRef] 
13. Dookie, B.; Jones, K.R.; Mohammed, R.; Garcia, G.W. Feed particle size preference and feed wastage in agouti (Dasyprocta leporina) reared intensively in the Republic of Trinidad and Tobago. Livest. Res. Rural Dev. 2018, 30, 1-8.

14. Jones, K.R.; Lall, K.R.; Garcia, G.W. Omnivorous Behaviour of the Agouti (Dasyprocta leporina): A Neotropical Rodent with the Potential for Domestication. Scientifica 2019, 2019, 5. [CrossRef] [PubMed]

15. Jones, K.R.; Lall, K.R.; Garcia, G.W. Haematological and serum biochemical reference values of healthy Agoutis (Dasyprocta leporina) reared intensively in Trinidad, Republic of Trinidad and Tobago. Livest. Res. Rural Dev. 2019, 31, 1-9. Available online: http://www.lrrd.org/lrrd31/1/kegan31005.html (accessed on 15 April 2019).

16. Lall, K.R.; Jones, K.R.; Garcia, G.W. Infectious Diseases of Six Non-Domesticated Neo-Tropical Animals in Trinidad and Tobago. Int. J. Trop. Vet. BioMed Res. 2018, 3, 1-31. [CrossRef]

17. Tardieu, L.; Adogwa, A.O.; Garcia, G.W. Didelphis species, neo-tropical animals with the potential for intensive production: Part 1 Review of taxonomy, natural history, general biology, animal behaviour, and nutrition. Trop. Agric. 2017, 94, 157-174.

18. Tardieu, L.; Adogwa, A.O.; Garcia, G.W. Didelphis species, Neo-tropical animals with the potential for intensive production: Part 2: Review of reproductive systems. Trop. Agric. 2017, 94, 312-334.

19. Jones, K.R.; Lall, K.R.; Garcia, G.W. Gross Anatomy of the Gastrointestinal Tract of a Red Brocket Deer (Mazama americana): A Case Study. J. Adv. Vet. Res. 2018, 8, 26-31.

20. Griffiths, H.J. Studies on Strongyloides agoutii from the agouti (Dasyptocta agouti). Can. J. Res. D 1940, 18, 173-190. [CrossRef]

21. Cameron, T.W.M.; Reesal, M.R. Studies on the endoparasitic fauna of Trinidad mammals. Can. J. Zool. 1951, 29, 276-289. [CrossRef]

22. Suepaul, R.; Charles, C.; Dziva, F. Aerobic microflora and endoparasites of freshly shot wild agouti (Dasyprocta leporina) in Trinidad, West Indies. J. Zoo Wildl. Med. 2016, 47, 1044-1048. [CrossRef]

23. Jones, K.R.; Garcia, G.W. A survey of the gastrointestinal parasites present in the Agouti (Dasyprocta leporina) reared intensively in Trinidad. Livest. Res. Rural Dev. 2017, 29, 1-7.

24. Jones, K.R.; Garcia, G.W. Observations on the endoparasitic load in captive reared agoutis (Dasyprocta leporina) without anthelminthic exposure in Trinidad, Republic of Trinidad and Tobago. Livest. Res. Rural Dev. 2018, 30, 1-8. Available online: http://www.lrrd.org/lrrd30/10/kegan30181.html (accessed on 10 March 2019).

25. Cassone, J.; Durette-Desset, M.C. Five species (three new) of trichostrongylid nematodes coparasites of Dasyprocta azarae, from Paraguay. Revue Suisse Zool. 1991, 98, 229-242. [CrossRef]

26. Noronha, D.; Vincente, J.J.; Pinto, R.M. A survey of new host records of nematodes form mammals deposited in the Helminthological Collection of the Oswaldo Cruz Institute (CHIOC). Rev. Bras. Zool. 2002, 19, 945-949. [CrossRef]

27. Vincente, J.J.; Rodriguez, H.O.; Gomes, D.C.; Pinto, R.M. Nematoides do Brazil. Parte V. Nematoides de mamiferos. Rev. Bras. Zool. 1997, 14,1-454. [CrossRef]

28. Durette-Desset, M.C.; Goncalves, A.Q.; Pinto, R.M. Trichostrongylina (Nematoda, Heligmosomoidea) coparaites in Dasyprocta fuliginosa Wagler (Rodentia, Dasyproctidae from Brazil, with re-establishment of the genus Avellaria Freitas and Lent and the description of two new species. Rev. Bras. Zool. 2006, 23, 509-519. [CrossRef]

29. Mendonca, I.L.D.; de Almieda, M.M.; Conde Junior, A.M.; Cavalante, R.R.; de Moura, G.S.; de Carvalho, M.A.M. Coproparasitic analysis of agouti (Dasyprocta sp.) in captivity. Cienc. Anim. Bras. 2006, 7, 285-288.

30. Goncalves, A.Q.; Bola, M.N.; Coura, J.R.; Pinto, R.M. New records of helminths if hystricomorphic rodents from the middle and high Rio Negro microregion, State of Amazonas, Brazil. Rev. Bras. Zool. 2006, 23, 716-726. [CrossRef]

31. Lainson, R.; Carneiro, L.; Silveira, F.T. Observations on the Eineria species of the Dasyprocta leporina (Linnaeus, 1758) (Rodentia: Dasyproctidae) for the state of Para, North Brazil. Mem. Inst. Oswaldo Cruz 2007, 102, 183-189. [CrossRef]

32. Goncalves, A.Q.; Pinto, R.M.; Durette-Desset, M.C. Parasitism of two zoonotic reservoirs Dasyprocta leporina and Dasyprocta fuliginosa (Rodentia) from the Amazonas with trichostrongylina nematodes (Heligmonellidae): Description of a new genus and a new species. Mem. Inst. Oswaldo Cruz 2007, 102, 763-768. [CrossRef] 
33. Macedo, L.E. Nematódeos Gastrintestinais Parasitos de Cutias (Dasyprocta spp.) do Município de Teresina-Piauí. Master's Thesis, Brasil Universidade, Federal de Minas Gerais Brazil, Belo Horizonte, Brazil, 2008; pp. 9-63.

34. Da Silva, M.K.; da Silva, A.S.; Olivieria, C.M.; Montiero, S.G. Gastrointestinal parasites of the agouti (Dasyprocta leporina). Cienc. Anim. Bras. 2008, 9, 128-131.

35. Zimmerman, D.M.; Douglass, M.; Reavill, D.R.; Greiner, E.C. Echinococcus oligarthrus cystic hydatidosis in Brazillian agouti (Dasyprocta leporina). J. Zoo Wildl. Med. 2009, 40, 551-558. [CrossRef] [PubMed]

36. Ramos, D.G.S.; Santos, A.R.G.L.O.; Freitas, L.C.; Correa, S.H.R.; Kempe, G.V.; Morgado, T.O.; Aguiar, D.M.; Wolf, R.W.; Rossi, R.V.; Sinkoc, A.L.; et al. Endoparasites of wild animals form three biomes in the State of Mato Grosso, Brazil. Arq. Bras. Med. Vet. Zootec. 2016, 68, 571-578. [CrossRef]

37. Costa, A.F.; Perriera, A.L.M.; Almeida, K.D.S. Agouti helminthological fauna (Dasyprocta spp.): Implications for commercial production-Review. Rev. Cient. Electron. Med. Vet. 2013, 21, 1-20.

38. Da Silva, M.K.; da Silva, A.S.; Soares, J.F.; Montiero, S.G. Treatment of agoutis (Dasyprocta leporina) naturally infected with helminths. Fac. Zootec. Vet. Agron. 2007, 14, 181-186.

39. Almeida, F.; Caldas, R.; Corre, C.; Rodriguez- Silva, R.; Siqueira, N.; Machado-Silva, J.R. Co-infection of the cestode Echinoccocus vogeli and the nematode Calodium hepaticum in the hystricomorphic rodent Agouti paca from a forest reserve in Acre, Brazil. J. Helminthol. 2013, 87, 489-493. [CrossRef]

40. De Freitas, F.L.C.; Mazzinghy, C.L.; da Costa Freitas, W.L.; Tebaldi, J.H.; Almeida, K.D.S. Parasitic gastritis in Cuniculus paca (Rodentia: Cuniculidae). Rev. Pathol. Trop. 2012, 41, 356-366. [CrossRef]

41. Ribiero, V.M.F.; de Souza, S.F.; Pinto, N.N.M.; Alves, A.L.F.; de Araujo Santos, F.G. Monitoring of the intestinal tract parasites load and of the sanitary management at the pacific breeding farm. Braz. Anim. Sci. 2015, 16, 608-614.

42. Ribiero, V.M.F.; Faino, A.L.; Peruquetti, R.C.; Souza, S.F.; Medeiros, L.S.; Karaccas, Y.; Santos, F.G.A. Evaluation of quickline efficacy in inactivating nematode eggs (Strongyloides spp.) parasites of paca (Cuniculus paca) created in captivity. Arq. Bras. Med. Vet. Zootec. 2017, 69, 989-996.

43. Figueiredo, M.A.P.; Manrique, W.G.; Nogueira, R.M.S. Survey of gastrointestinal parasites of the centre for screening of wild animals for Sao Luis, Maranhao State, Brazil. Veterinaria 2018, 34, 60-68. [CrossRef]

44. Matamoro, Y.; Velazquez, J.; Pashov, B. Parasitos intestinalis del tepezcuinte, Agouti paca (Rodentia: Dasyproctidae) en Costa Rica. Rev. Biol. Trop. 1991, 39, 173-176.

45. Ramirez-Hererra, O.; Rodriguez-Vivas, R.I.; Montes-Perez, R.; Torres-Acosta, J.F. Seguimiento annual de la parasitosis gastrointestinal del tepezcuintle, Agouti paca (Rodentia: Agoutidae) en cautiverio en la tropic mexicano. Reista Biol. Trop. 2001, 49, 1171-1176.

46. Sato, H.; Okamato, M.; Ohbayashi, M.; Basanez, M.G. A new cestode, Raillietina (Raillietina) oligocapsultata n. sp. and R. demerariensis (Daniels 1895) from Venezuelan mammals. Jpn. J. Vet. Res. 1988, 36, 31-45. [PubMed]

47. Morales, G.A.; Guzman, V.H.; Wells, E.A.; Angel, D. Polycystic echinococcus in Columbia: The larval cestodes in infected rodents. J. Wildl. Dis. 1979, 15, 421-428. [CrossRef] [PubMed]

48. Gardner, S.L.; Rausch, R.L.; Camacho, O.C.J. Echinococcus vogeli Rausch and Bernstein, 1972, from the paca, Cuniculus paca L. (Rodentia: Dasyproctidae), in the Departmento de Santa Cruz, Bolivia. J. Parasitol. 1988, 74, 399-402. [CrossRef]

49. Gardner, S.L.; Dursahinhan, T.; Racz, G.R.; Batsaikhan, N.; Ganzorig, S.; Tinnin, D.S.; Damdinbazar, D.; Wood, C.; Peterson, A.T.; Alandia, E.; et al. Sylvatic species of Echinococcus for rodent intermediate hosts in Asia and South America. Mus. Texas Tech Univ. 2013, 318, 1-12.

50. Tantalean, M.V.; Angulo, J.V.; Martinez, R.R.; Diaz, S.M. First record of the Echinococcus vogeli (Cesotda, Taeniidae) metacestod in finding in Iquitos, Peru. Peruv. J. Parasitol. 2012, 20, 74-76.

51. Mayor, P.; Baquedano, L.E.; Sanchez, E.; Aramburu, J.; Gomes-Puerta, L.A.; Mamani, J.M.; Gavidia, C.M. Polycystic echinococcosis in Pacas, Amazon region, Peru. Emerg. Infect. Dis. 2015, 21, 456-459. [CrossRef]

52. Meneghelli, U.G.; Martinelli, A.L.C.; Velludo, M.A.S.L. Cisto de Echinococcus vogeli em figado de paca (Cuniculus paca) origniaria do estado do Acre, Brazil. Rievista Soc. Bras. Med. Trop. 1990, 23, 153-155. [CrossRef]

53. D'Alessandro, A.; Moraes, M.A.P.; Raick, A.N. Polycystic hydatid disease in Brazil, report of five new human cases and a short review of other published observations. Rievista Soc. Bras. Med. Trop. 1996, 29, $219-227$. [CrossRef] 
54. Basset, D.; Girou, C.; Nozais, I.P.; D’Hermies, F.; Hoang, C.; Gordon, R.; D'Alessandro, A. Neotropical echinococcosis in Suriname: Echinoccocus oligarthrus in the orbit and Echinococcus vogeli in the abdomen. Am. J. Trop. Med. 1998, 59, 787-790. [CrossRef]

55. Grisi, L. Parasitic zoonoses: Selected review of some diseases in South America. Ann. Parasitol. Hum. Comp. 1990, 65, 79-82. [CrossRef] [PubMed]

56. Tappe, D.; Stich, A.; Frosch, M. Emergence of Polycystic Neotropical echinococcosis. Emerg. Infect. Dis. 2008, 14, 292-297. [CrossRef] [PubMed]

57. Faust, E.C. Notes on Helminths in Panama: 1 Taxorchis schistocotyle (Fischoeder, 1901), from the Panamanian capybara, Hydrochoerus isthmus Goldman, 1912. J. Parasitol. 1935, 21, 323-331. [CrossRef]

58. Moulton, J.E.; Heuschele, W.P.; Sheridan, B.W. Balantidiasis in the Capybara. Cornel. Vet. 1961, 51, 350.

59. Santarem, V.A.; Tostes, R.A.; Alberti, H.; Sanches, O.C. Fasciola hepatica in capybara. Acta Trop. 2006, 98, 311-313. [CrossRef]

60. Albuquerque, G.R.; Berto, B.P.; Catenacci, L.S.; Nogueira, S.S.C.; Nogueira-Filho, S.L.G.; Lopes, C.W.G. Eimerid coccidian from capybaras (Hydrochoerus hydrochaeris) in southern Bahia, Brazil. Presq. Vet. Bras. 2008, 26, 323-328. [CrossRef]

61. Tavares, E.D.R.; Campiao, K.M.; Costa-Pereira, R.; Paiva, F. Helminth parasites of wildlife vertibrates in Mato Grosso do Sul, Brazil. Iheringia Ser. Zool. 2017, 107, e2017106. [CrossRef]

62. Bonuti, M.R.; Nascimento, A.A.; Mapelli, E.B.; Arantes, I.G. Helmintos gastrintestinais de capivaras (Hydrochoerus hydrochoerus) na sub-negiao de Paiaguas, Pantanal do Mato Grosso do Sul, Brazil. Semin. Cienc. Agrar. 2002, 23, 57-62. [CrossRef]

63. Da Silva, M.K.; da Silva, A.S.; Oliveira, C.B.; Soares, J.F.; Monteiro, S.G. Occorrencia de Eimeria ichiloensis em capivara (Hydrochaeris hydrochaeris) de criatorio. Arq. Cienc. Vet. Zool. 2007, 10, 129-131.

64. El-Kouba, M.M.A.N.; Marques, S.M.T.; Pilati, C.; Hamann, W. General aspects of Fascioliasis and Endoparasitic diseases in capybaras (Hydrochoerus hydrochaeris Linnaeus, 1766) from three parks in the State of Parana, Brazil. Vet. Foco 2008, 6, 4-15.

65. Sinkoc, A.L.; Brum, J.G.W.; Muller, G. Gastrointestinal Helminths of Capybara (Hydrochoerus hydrochaeris, Linnaeus, 1766) in Cattle Breeding Farms in the Area of the Ecological Reserve of Taim, Rio Grande. Braz. Arch. Biol. Technol. 2009, 52, 327-333. [CrossRef]

66. Souza, G.T.R.; Ribeiro, T.S.; Antonucci, A.M.; Ueda, B.H.; Carniel, M.K.; Karling, L.C.; Eiras, J.C.; Takemoto, R.M.; Pavanelli, G.C. Endoparasite Fauna of Wild Capybaras (Hydrochoerus hydrochaeris) (Linnaeus, 1766) from the Upper Parana River Floodplain, Brazil. Aquat. Mamm. 2015, 41, 213-221. [CrossRef]

67. Dracz, R.M.; Ribeiro, V.M.A.; Pereira, C.A.J.; Lima, W.D.S. Occurrence of Fasciola hepatica (Linnaeus, 1758) in capybara (Hydrochoerus hydrochaeris) (Linnaeus, 1766) in Minas Gerais, Brazil. Braz. J. Vet. Parasitol. 2016, 25, 364-367. [CrossRef] [PubMed]

68. Sprenger, L.K.; Yoshitani, U.Y.; Buzatti, A.; Molento, M.B. Occurrence of gastrointestinal parasites in wild animals in the State of Parana, Brazil. An. Acad. Bras. Cienc. 2018, 90, 231-238. [CrossRef]

69. Costa, C.A.F.; Catto, J.B. Helmintos parasitos de Cabivaras (Hydrochaeris hysrochaeris) na sub-regiao da Nhecolandia, Pantanal sul-mato-grossense. Rev. Bras. Biol. 1994, 54, 39-48.

70. Sinkoc, A.L.; Brum, F.A.; Muller, G.; Brum, J.G.W. Helmintos parasitos de Capivara (Hydrochaerus hydrochaeris L.1766) na regionde Aracatuba, Sau Paulo, Brazil. Arq. Inst. Biol. 2004, 71, 329-333.

71. Wendt, L.C.; Muller, G.; Pinheiro, M.; Santos, L.M.J.F.; Silva, M.A.M.P.; Gonzales, H.G.; Rulas, J.L.; Farias, N.A. Gastrointestinal helminths of capybara (Hydrochoerus hydrochaeris) in semi-intensive breeding systems in the south region of Rio Do Sul state, Brazil. Sci. Anim. Health 2016, 4, 283-293. [CrossRef]

72. Meireles, M.V.; Soares, R.M.; Bonello, F.; Gennari, S.M. Natural infection with zoonotic subtype of Cryptosporidium paroum in Capybara (Hydrochoerus hydrochaeris) from Brazil. Vet. Parasitol. 2007, 147, 166-170. [CrossRef]

73. Gurgel, A.C.F.; Sartori, A.D.S.; de Araujo, F.A.P. Eimeriosis in Capybara (Hydrochaeris hydrochaeris) in the state of Rio Grande do Sul, Brazil. Parasitol. Lat. 2007, 62, 76-78.

74. Bellato, V.; de Souza, A.P.; Sartor, A.P.; Veiga, L.P.H.N.; Centenaro, F. Fasciola hepatica occurrence in capybaras (Hydrochaeris hydrochaeris) and bovines (Bos taurus) in Timbo, SC, Brazil. Rev. Cienc. Agrovet. 2009, 8, 66-70.

75. Chiacchio, R.G.-D.; Prioste, F.E.S.; Vanstreels, R.E.T.; Knobl, T.; Kobler, M.; Miyashiro, S.I.; Matushima, E.R. Health evaluation and survey of zoonotic pathogens in free-ranging capybaras (Hydrochoerus hydrochaeris). J. Wildl. Dis. 2014, 50, 496-504. [CrossRef] [PubMed] 
76. Corriale, M.J.; Milano, A.M.F.; Gomez-Munoz, M.A.; Herrera, E.A. Prevalence of gastrointestinal parasites in a natural population of Capybaras, Hydrochoerus hydrochaeris, in Esteros del Ibera (Argentina). Rev. Ibero Lat. Parasitol. 2011, 70, 189-196.

77. Moriena, R.A.; Ortiz, M.I.; Racioppi, O.; Alverez, J.D. Fallibility of coprology to differentiate eggs belonging to Fasciola hepatica and Taxorchis schistocotyle in Capybaras (Hydrochoerus hydrochaeris). Rev. Vet. 2012, 23, 147-148.

78. Robles, M.D.R.; Eberhardt, M.A.T.; Bain, O.; Beldomenico, P.M. Redescription of Echinocoleus hydrochoeri (Travassos, 1916) (Nematoda: Trichuridae) from Hydrochoerus hydrochaeris Linnaeus, 1766 (Rodentia: Caviidae) from Argentina. J. Parasitol. 2013, 99, 624-633. [CrossRef]

79. Eberhardt, A.T.; Robles, M.D.S.; Monje, L.D.; Beldomenico, P.M.; Callejon, R. A new Trichuris species (Nematoda: Trichuridae) from capybaras: Morphological-molecular characterization and polygenetic relationships. Acta Trop. 2019, 190, 244-252. [CrossRef]

80. Casas, M.C.; Zalles, L.M.; Patrick, M.J.; Dailey, M. Intestinal Helminths of Capybara (Hydrochaeris hydrochaeris) from Bolivia. J. Helminthol. Soc. Wash. 1995, 62, 87-88.

81. Casas, M.C.; Duszynski, D.W.; Zalles, L.M. Three new eimerians in capybara (Hydrochaeris hydrochaeris) populations form eastern Bolivia and southern Venezuela. J. Parasitol. 1995, 81, 247-251. [CrossRef]

82. Salas, V.; Herreria, E.O. Intestinal Helminths of Capybara (Hyrdochoerus hydrochoeris) from Venezuela. Mem. Inst. Oswaldo Cruz 2004, 99, 563-566. [CrossRef]

83. Rodriguez-Duran, A.; Palma, L.C.B.; Florez, R.P. Main gastrointestinal protozoa in wild capybara (Hydrochoerus hydrochaeris) in a village in the municipality of Arauca, Columbia. Zootec. Trop. 2015, 33, 261-268.

84. Eberhardt, A.T.; Costa, S.A.; Marini, M.C.; Racca, A.; Baldi, C.J.; Robles, M.R.; Moreno, P.G.; Beldomenico, P.M. Parasitism and Physiological Rade-Offs in Stressed Capybaras. PLoS ONE 2013, 8, e70382. [CrossRef]

85. Moreno, P.G.; Eberhardt, M.A.T.; Lamattina, D.; Previtall, M.A.; Beldomenico, P.M. Intra-phylum and inter-phylum associations among gastrointestinal parasites in two wild mammal species. Parasitol. Res. 2013, 112, 3295-3304. [CrossRef] [PubMed]

86. Cueto, G.R. Diseases of the Capybara. In Capybara: Biology, Use and Conservation of an Exceptional Neotropical Species; Moreira, J., Ferraz, K.M., Herrera, E.A., Macdonald, D.W., Eds.; Springer: New York, NY, USA, 2013; pp. 169-184.

87. Wolfgang, R.W. Studies on endoparasitic fauna of Trinidad mammals. IX. Didephonema, a new species of nematode from marsupials. Can. J. Zool. 1953, 31, 519-521.

88. Wolfgang, R.W. Studies on endoparasitc fauna in Trinidad mammals. VIII. Parasites of Marsupials. Can. J. Zool. 1951, 29, 352-373. [CrossRef]

89. Sandars, D.F. On some Trematodes from the manicou, Didelphis marsupialis insularis (Allen) from the West Indies. J. Helminthol. 1958, 32, 145-158. [CrossRef]

90. Ernest, J.V.; Cooper, C., Jr.; Chobotar, B. Isospora boughtoni Volk, 1938 and Isospora sp. (Protozoa: Eimeriidae) from an opossum Didelphis marsupialis. Bull. Wildl. Dis. Assoc. 1969, 5, 406-409.

91. Nettles, V.F.; Prestwood, A.K.; Davidson, W.R. Severe parasitism in an opossum. J. Wildl. Dis. 1975, 11, 419-420. [CrossRef]

92. Prestwood, A.K. Didelphostrongylus hayesi gen. et. sp. n. (Metastrongyloidea: Filaroididae) from opossum, Didelphis marsupialis. J. Parasitol. 1976, 62, 272-275. [CrossRef]

93. Naiff, R.D.; Arias, J.R. Besnoitia (Protozoa: Toxoplasmatinae) isolado de mucuras Didelphis marsupialis na regiao Amazonica, Brazil. Mem. Inst. Oswaldo Cruz 1983, 78, 43-435. [CrossRef]

94. Rosenthal, B.M.; Lindsay, D.S.; Dubey, J.P. Relationship among Sarcocystis species transmitted by New World opossum (Didelphis spp.). Vet. Parasitol. 2001, 95, 133-142. [CrossRef]

95. Tantalean, M.; Diaz, M.; Sanchez, N.; Portocarrero, H. Endoparasites of small mammals from north-eastern Peru 1: Helminths of marsupials. Rev. Peru Biol. 2010, 17, 207-213.

96. Valerio-Campos, I.; Chinchilla-Carmona, M.; Duszynski, W. Eimeria marmosopos (Coccidia: Eimeriidae) from the Opossum Didelphis marsupialis L., 1758 (Didelphimornpha: Didelphidae), in Costa Rica. Comp. Parasitol. 2015, 82, 148-150. [CrossRef]

97. Chinchilla, M.; Valerio, I.; Duszynski, D. Endogenous life cycle of Eimeria marmosopos (Apicomplexa: Eimeriidae) from the opossum, Didelphis marsupialis (Didelphimorphia, Didelphidae) in Costa Rica. J. Parasitol. 2015, 101, 436-443. [CrossRef] [PubMed] 
98. Acosta-Virgen, K.; Lopez-Caballero, J.; Garcia-Prieto, L.; Mata-Lopez, R. Helminths of three species of opossums (Mammalia, Didelphidae) from Mexico. Zookeys 2015, 511, 131-152.

99. Alicata, J.E. The occurrence of Moniezia benedeni in a peccary. J. Parasitol. 1931, 19, 83.

100. Schwartz, B.; Alicata, J.E. Descriptions of two parasitic nematodes from the Texas peccary. Proceeding of U.S. Natl. Mus. 1933, 82, 1-6. [CrossRef]

101. Samuel, W.M.; Low, W.A. Parasites of the Collared Peccary from Texas. J. Wildl. Dis. 1970, 6, 16-23. [CrossRef]

102. Corn, J.L.; Pence, D.B.; Warren, R.J. Factors affecting helminth community structure of adult collared peccaries in southern Texas. J. Wildl. Dis. 1985, 21, 254-263. [CrossRef]

103. Wilber, P.G.; Hellgren, E.C.; Gabor, T.M. Coccidia of the Collared Peccary (Tayassu tajacu) in Southern Texas with description of three new species of Eimeria (Aplicomplexa: Eimeriidae). J. Parasitol. 1996, 82, 624-629. [CrossRef]

104. Chitwood, M.B.; Cordero de Campillo, M. Texicospirura turki gen et sp. n. (Nematoda: Spiruroidea) from the stomach of the peccary in the United States, and a key to the genera of Ascaropsinae. J. Parasitol. 1966, 52, 307-310. [CrossRef]

105. Sampson, K.S.; Donaldson, B.R. Parasites of Javalina in New Mexico. Bull. Wildl. Dis. Assoc. 1968, 4, 131. [CrossRef]

106. Gruver, K.S.; Guthrie, J.W. Parasites and Selected Diseases of Collared Peccaries (Tayassu tajacu) in the Trans-Pecos Region of Texas. J. Wildl. Dis. 1996, 32, 560-562. [CrossRef] [PubMed]

107. Texeira de Freitas, J.F.; Lent, H. Notas sobre Gongyloneminae Hall, 1916. Mem. Inst. Oswaldo Cruz 1937, 32, 299-304. [CrossRef]

108. Neto, J.B.; Thatcher, V.E. Estudos parasitologicos preliminaries en tayassuideos (Tayassu tajacu) na Amazonia Central. Revista Bras. Med. Vet. 1986, 8, 175-184.

109. Vincente, J.J.; Muniz-Pereira, L.C.; Noranha, D.; Pinto, R.M. Description of Males of Parabronema pecariae Ivaschkin, 1960 (Nematoda, Habronematoidea) parasitizing peccaries (Mammalia, Tayassuidae) in Brazil. Mem. Inst. Oswaldo Cruz 2000, 95, 849-851. [CrossRef]

110. Carlos, N.E.; Tantalean, M.; Leguia, P.V.G.; Alcazar, G.P.; Donadi, S.R. Frequency of helminths in wild white lipped peccaries (Tayassu pecari Link, 1795) from protected areas of Madre de Dios department, Peru. Neotrop. Helminthol. 2008, 2, 48-53.

111. Farret, M.H.; Fanfa, V.D.R.; da Silva, A.S.; Monteiro, S.G. Gastrointestinal protozoa in Tayassu pecari kept in captivity in Brazil. Cienc. Agrar. 2010, 31, 1041-1044. [CrossRef]

112. Sprent, J.F.A. Ascaridoid nematodes of South American Mammals, with a definition of a new genus. J. Helminthol. 1982, 56, 275-295. [CrossRef]

113. Romero-Castanon, S.; Ferguson, B.G.; Guiris, D.; Gonzales, D.; Lopez, S.; Paredes, A.; Weber, M. Comparative Parasitology of Wild and Domesticated Ungulates in the Selva Lacandona, Chiapas, Mexico. Comp. Parasitol. 2008, 75, 115-126. [CrossRef]

114. Mukul-Yerves, J.M.; Zapata-Escobedo, M.D.R.; Montez-Perez, R.C.; Rodriguez-Vivas, R.I.; Torres-Acosta, J.F. Gastrointestinal and ectoparasites in wildlife-ungulates under captive and free-living conditions in the Mexican tropic. Revista Mex. Cienc. 2014, 5, 459-469.

115. Valdes Sanches, V.V.; Saldana Patino, A.; Pineda Segundo, V.J.; Camacho Sandoval, J.A.; Charpentier Esquivel, C.V.; Cruz Sanchez, T.A. Gastrointestinal parasites of captive Odocoileus virginianus and Tayassu tajacu from Panana Republic. Acta Zool. Mex. 2010, 26, 477-480.

116. Limachi-Quinajo, R.; Nallar-Gutierrez, B.; Alandia-Robles, E. Gastrointestinal parasites in Free-ranging Tayassu pecari and Pecari tajacu from the Pilon Lajas Biosphere Reserve and indigenous territory, Beni-Bolivia. Neotrop. Helminthol. 2014, 8, 269-277.

117. Hellgren, E.C.; Lochmiller, R.L.; Grant, W.E. Infection of Captive Adult Collared Peccaries, Dioctyles tajucu (Woodbourne, 1968), with the Nematode, Ascaris suum (Goeze, 1782). Proc. Helminthol. Soc. Wash. 1984, $51,160-161$.

118. Harwell, G.M.; Davis, D.S.; Robinson, R.M.; Galvin, T.J. Experimental infection of Collared Peccary (Dioctyles tajacu angulatus) with the Swine Kidney worm (Stephanurus dentatus). J. Wildl. Dis. 1977, 13, 445-447. [CrossRef] [PubMed] 
119. De Freitas Soares, F.E.; de Queiroz, J.H.; de Araujo, J.V.; Rodriguez, M.G.R.; de Oliviera Tavela, A.; Aguiar, A.R.; Lacerda, T.; Ferraz, C.M.; Rangel, M.C.V.; Senna, T.; et al. Action of proteases of the namatophagous fungi Pochonia chlamydosporia on Ascaris suum eggs of collared peccary (Pecari tajacu). Afr. J. Microbiol. Res. 2015, 9, 1883-1886.

120. Cameron, W.M. Studies on the endoparasitic fauna of Trinidad Mammals. I. Some parasites of Trinidad deer. Can. J. Res. D 1935, 13, 89-96. [CrossRef]

121. Cameron, W.M. Studies on the endoparasitic fauna of Trinidad Mammals. II. Additional parasites from Trinidad deer. Can. J. Res. D 1936, 14, 1-5. [CrossRef]

122. Cameron, W.M. Studies on the endoparasitic fauna of the Trinidad Mammal. IV. Further parasites of the Trinidad deer. Can. J. Res. D 1936, 14, 165-167. [CrossRef]

123. Nasciemento, A.A.; Bonuti, B.R.; Mapeli, E.B.; Tebaldi, J.H.; Arantes, I.G.; Zettermann, C.D. Natural Trichostrongyloidea Cram, 1927 infection in deer (Mammalia: Cervidae) from the State of Mato Grosso do Sul and Sao Paulo. Braz. J. Vet. Anim. Sci. 2000, 37, 153-158.

124. Marques, S.M.T.; de Quadros, R.M.; Mazzolli, M.; de Jesus, J.R. Gastrointestinal parasites in the grey brocket deer (Mazama gouazoubira) from rural areas in planalt region to Santa Catarina, Brazil. Vet. Foco 2007, 5, 3-9.

125. Lux Hoppe, E.G.; Tebaldi, J.H.; Naciemento, A.A. Helminthological screening of free-ranging grey brocket deer (Mazama gouazoubira Fischer, 1817 (Cervidae: Odocoileini) from Brazilian Panatanal wetlands, with consideration on Pygarginema verrucosa (Molin, 1860) Kadenatzil, 1948 (Spirocercida: Ascaropsinae). Braz. J. Biol. 2010, 70, 417-423.

126. Gomez-Puerta, L.A.; Pacheco, J.; Gonzales-Viera, O.; Lopez-Urbina, M.T.; Gonzales, A.E. The taruca (Hippocamelus antisensis) and the red brocket deer (Mazama americana) as intermediate host of Taenia hydarigena in Peru, morphological and moleculuar evidence. Vet. Parasitol. 2015, 212, 465-468. [CrossRef] [PubMed]

(C) 2019 by the authors. Licensee MDPI, Basel, Switzerland. This article is an open access article distributed under the terms and conditions of the Creative Commons Attribution (CC BY) license (http://creativecommons.org/licenses/by/4.0/). 